Boston University School of Law

Scholarly Commons at Boston University School of Law

Faculty Scholarship

Spring 2002

\title{
Welfare Implications of Costly Litigation Under Strict Liability
}

Keith N. Hylton

Boston University School of Law

Follow this and additional works at: https://scholarship.law.bu.edu/faculty_scholarship

Part of the Litigation Commons

\section{Recommended Citation}

Keith N. Hylton, Welfare Implications of Costly Litigation Under Strict Liability, in 4 American Law and Economics Review 18 (2002).

Available at: https://scholarship.law.bu.edu/faculty_scholarship/790

This Article is brought to you for free and open access by Scholarly Commons at Boston University School of Law. It has been accepted for inclusion in Faculty Scholarship by an authorized administrator of Scholarly Commons at Boston University School of Law. For more information, please contact lawlessa@bu.edu. 


\section{HEINONLINE}

DATE DOWNLOADED: Sat Sep 24 20:15:19 2022

SOURCE: Content Downloaded from HeinOnline

Citations:

Bluebook 21st ed.

Keith N. Hylton, Welfare Implications of Costly Litigation under Strict Liability, 4 AM. L. \& ECON. REV. 18 (2002).

ALWD 7th ed.

Keith N. Hylton, Welfare Implications of Costly Litigation under Strict Liability, 4 Am. L. \& Econ. Rev. 18 (2002).

APA 7th ed.

Hylton, K. N. (2002). Welfare implications of costly litigation under strict liability. American Law and Economics Review , 4(1), 18-43.

Chicago 17th ed.

Keith N. Hylton, "Welfare Implications of Costly Litigation under Strict Liability," American Law and Economics Review 4, no. 1 (Spring 2002): 18-43

McGill Guide 9th ed.

Keith N. Hylton, "Welfare Implications of Costly Litigation under Strict Liability" (2002) 4:1 Am L \& Econ Rev 18.

AGLC 4th ed.

Keith N. Hylton, 'Welfare Implications of Costly Litigation under Strict Liability' (2002) 4(1) American Law and Economics Review 18

MLA 9th ed.

Hylton, Keith N. "Welfare Implications of Costly Litigation under Strict Liability." American Law and Economics Review , vol. 4, no. 1, Spring 2002, pp. 18-43. HeinOnline.

OSCOLA 4th ed.

Keith N. Hylton, 'Welfare Implications of Costly Litigation under Strict Liability' (2002) 4 Am L \& Econ Rev 18

Provided by:

Fineman \& Pappas Law Libraries

-- Your use of this HeinOnline PDF indicates your acceptance of HeinOnline's Terms and Conditions of the license agreement available at https://heinonline.org/HOL/License

-- The search text of this PDF is generated from uncorrected OCR text.

-- To obtain permission to use this article beyond the scope of your license, please use: Copyright Information 


\section{Welfare Implications of Costly Litigation under Strict Liability}

Keith N. Hylton, Boston University

This article examines a model of strict liability with costly litigation and presents conditions under which (1) potential injurers take optimal precautions, (2) increasing the cost of litigation enhances precaution and social welfare, (3) the optimal level of liability exceeds the compensatory level, and (4) increasing the rate of settlement enhances social welfare. The results have implications for controversies surrounding fee shifting, optimal damage awards (e.g., punitive damages), and the social desirability of settlement. The most striking implication is that fee shifting in favor of prevailing plaintiffs is socially desirable in low-transaction-cost settings.

\section{Introduction}

This article examines the welfare implications of costly litigation in a regime of strict liability. There are several articles on this subject, but they emphasize different results, and some of the results are difficult to reconcile. ${ }^{1}$ I offer a simple framework that incorporates, generalizes, and

I thank Michael Meurer and Steven Shavell for helpful comments on earlier drafts and take full responsibility for errors and omissions.

Send correspondence to: Keith N. Hylton, Boston University, School of Law, 765 Commonwealth Avenue, Boston, MA 02215; Fax: (617) 353-3077; E-mail: knhylton @bu.edu.

1. See Hylton (1990); Kaplow (1986); Polinsky and Rubinfeld (1988a, 1988); RoseAckerman and Geistfeld (1987); Shavell (1982a). I should note that these analyses (and this article) differ substantially from that of earlier analyses of strict liability, such as Posner (1973). The key difference is that the earlier work does not explicitly consider the influence of litigation costs on the injurer's care decision. On the other hand, the later articles focus only on the injurer's care decision, whereas Posner's analysis considers activity level effects as well. Compare Shavell (1982a) with Menell (1983), suggesting conflicting implications on the social desirability of litigation-later reconciled in Kaplow (1986) and Rose-Ackerman and Geistfeld (1987). 
reconciles old results and offers new results as well. I examine the following questions: (1) Will injurers take optimal precautions? (2) What are the effects of increasing litigation costs on precaution and on social welfare? (3) What is the optimal level of liability? (4) What are the welfare implications of settlement?

One issue that recurs in analyzing these questions is the productivity of care on the part of the injurer in reducing harms to victims. ${ }^{2}$ Liability provides a benefit to the extent it reduces harms by inducing injurers to take care. However, this benefit depends on the productivity of injurer care. If harms are unresponsive to care, or care unresponsive to liability, the benefit from liability will be negligible. If we define the deterrence benefit from liability as the avoided harms net of avoidance costs, additional liability is desirable only if care is sufficiently productive that the marginal deterrence benefit from additional liability exceeds the marginal cost of litigation. For simplicity, I will define care as productive if this condition holds. Since the optimal level of liability equates the marginal deterrence benefit and marginal litigation cost, this condition will not hold for liability levels above the optimal one. The key results in this study depend on whether this productivity condition holds at certain liability levels.

First, I show that injurers take too little care relative to the social optimum when (1) settlement is not permitted or (2) the entire settlement surplus goes to the injurer. Otherwise-in essence, if settlements occur and the victim receives part of the surplus-it is unclear whether injurers will exercise socially optimal precaution under strict liability. ${ }^{3}$

Second, I derive conditions under which increasing the cost of litigation leads to a reduction in social welfare. Generally the results are ambiguous, though there are two important cases in which the welfare effects are clear: (1) when the severity of the victim's harm is independent of the injurer's care level, welfare is decreasing in the victim's litigation cost; and (2) when care is productive (in the sense defined above), welfare is increasing in the injurer's litigation cost.

The third and key result of this study concerns the optimal level of liability. I show that setting the damage award equal to the sum of the victim's loss and the victim's litigation cost is socially optimal if (1) care is productive (at lower levels of liability), and (2) settlement is not permitted or the entire settlement surplus goes to the injurer. When care is not productive, or when plaintiff and defendant share the settlement

2. Polinsky and Rubinfeld (1988b) was the first article to point out the importance of the productivity of care in evaluating the welfare implications of strict liability.

3. This extends Hylton (1990), which examines a model in which settlements do not occur and shows that injurers exercise socially inadequate care under strict liability. 
surplus, the optimal award is less than the sum of the victim's loss and litigation cost.

Fourth, this article suggests a different view on the welfare implications of settlement. Under the American litigation cost-allocation rule, the welfare implications of settlement are ambiguous. The reason is that settlement reduces the total cost of litigation, which benefits society, but it also dilutes incentives to take care since the expectation of settlement reduces the injurer's expected liability. ${ }^{4}$ I show that under a rule that shifts the plaintiff's litigation cost to the defendant, increasing the rate of settlement definitely enhances social welfare. ${ }^{5}$

These results have implications for controversies surrounding optimal damages, fee shifting, and settlement; though care must be taken in translating the results of this model into useful statements about optimal remedies and procedural rules. I argue below that the two conditions upon which many of the results hinge-whether care is productive and whether injurers appropriate the entire settlement surplus-are likely to be satisfied in settings where the cost of transacting between the potential victim and potential injurer are low. This suggests that where transaction costs are low, the optimal damage award under strict liability is simply the sum of the victim's harm and litigation cost. It follows easily that litigation

4. See Polinsky and Rubinfeld (1988a). Shavell $(1996,1997)$ argues that the conflict between cost reduction and deterrence dilution is irrelevant, because society can use fines or subsidies to regulate the quantity of litigation and vary the level of the damage award in order to control incentives for care. For an analysis of optimal twoinstrument or "decoupled" regulation, see Polinsky and Che (1991). The model in this article, consistent with Polinsky and Rubinfeld (1988a), assumes that the only instrument available to courts is the damage award. This assumption is probably appropriate, given that the administrative costs of using fines or subsidies to control the volume of litigation may be prohibitive. For an analysis of the administrative difficulties of using a tax or subsidy scheme to control the volume of litigation (in the context of Rule 68), see Hylton (1996b).

5. This implies that the welfare tradeoff result in Polinsky and Rubinfeld (1988a) holds forall litigation cost-allocation rules other than the proplaintiff (losing defendant pays) or British (losing party pays). Since this article examines a model of strict liability in which plaintiffs always win their suits, the British and proplaintiff rules are the same in this analysis. For a discussion of alternative litigation cost-allocation rules, see Shavell (1982b) (examining American, British, prodefendant, proplaintiff allocation rules). The finding here that an increase in settlement is always socially desirable under proplaintiff fee shifting suggests that some argument other than the care reduction effect must be made to show that settlement may be undesirable. Although I have not incorporated it into this model, one could argue that settlement is undesirable because it reduces the public stock of common law decisions, which provide information; see Fiss (1984). A discussion of arguments against settlement can also be found in Shavell (1997). 
cost-allocation rules that shift the prevailing plaintiff's litigation costs to the defendant (e.g., the British rule) are likely to be socially preferable in such settings. And whether or not transaction costs are low, this analysis suggests that the optimal adjustment to compensatory damages will, as a general rule, not exceed the victim's cost of litigation. ${ }^{6}$ Since this model does not examine intentional injuries, I do not claim that my results have any implications for punitive awards in cases of intentional harm.

I have tried to state the results as plainly as possible, with few technical terms. The proofs in the text are simple and easy to interpret intuitively; the more complicated proofs are provided in the Appendix. Section 2 provides an informal discussion of key results and implications for the literature. Section 3 presents the model. Section 4 discusses implications.

\section{Literature Review and Informal Analysis}

The results in this article substantially modify the conclusions of four articles concerning the welfare implications of costly litigation under strict liability: Hylton (1990), Menell (1983), Polinsky and Rubinfeld (1988a), and Polinsky and Rubinfeld (1988b).

Let us start with Menell (1983) and Hylton (1990), whose results are more closely related than appears at first glance. The Menell article shows that private and social incentives to preclude an additional lawsuit by taking care are the same under strict liability. The reason is as follows. The social cost of the marginal lawsuit is the sum of the injurer and victim's litigation costs. Thus, if both parties spend $\$ 20$ on litigation, the social cost of the marginal lawsuit is $\$ 40$. To the injurer, the cost of the marginal lawsuit is his liability to the marginal victim plus his litigation cost. But in the case of the marginal victim, liability is equal to the victim's litigation cost, since the marginal victim is the one who is indifferent toward filing and not filing his lawsuit. Thus, the cost to the injurer of the marginal lawsuit will be $\$ 40$, the same as the social cost of the marginal lawsuit. It follows that the private and social incentives to preclude litigation are identical.

The Hylton article shows that strict liability results in too little care relative to the social optimum ("underdeters") in a model in which litigants do not settle their cases. The Menell and Hylton results are related, as I show below, for the simple reason that Menell's finding that the private and social suit-preclusion incentives are identical assumes that litigants do not settle or the injurer takes the entire settlement surplus. Under either of

6. Compare this to the approach urged in Polinsky and Shavell (1998), which requires the court to divide the damage award by the probability of liability. 
these conditions, the suit-preclusion incentive does not push the injurer's care away from the optimal level. This leaves two externalities attributable to litigation costs as sources of inefficiency: (1) litigation does not internalize the losses of victims who do not sue, because the litigation cost exceeds the anticipated award, and (2) litigation does not internalize the litigation costs of victims who do sue. Because these externalities cause injurers to take too little care relative to the social optimum, strict liability underdeters in a model in which litigants do not settle.

This article considers what happens when litigants can settle their disputes. In this model, it is unclear whether injurers exercise socially optimal precaution. There are two reasons for this ambiguity. First, with settlement the expected "net litigation cost" to the victim may be negative. For example, if the victim's litigation cost is $\$ 20$, and his expected portion of the settlement surplus is $\$ 25$, his expected net cost of litigation is $-\$ 5$, and he is overcompensated in settlement. If this is the case, the private incentive to take care may exceed the social incentive. Second, with settlement the private incentive to preclude a lawsuit may diverge from the social incentive, contrary to Menell's result. The injurer will have an incentive to take too much care relative to the social optimum, because he will add the victim's expected portion of the settlement surplus to his estimate of the cost of litigation. Thus, if the victim's expected portion of the settlement surplus is positive, the suit-preclusion incentive will tend to overdeter.

Polinsky and Rubinfeld (1988b) examines the optimal adjustment to compensatory damages, concluding that it may be positive or negative, depending largely on the productivity of care. The results here are consistent; however, this article extends the Polinsky-Rubinfeld analysis by setting out the conditions under which the optimal award will include the victim's litigation cost as an element and by examining the implications of settlement for the optimal level of liability. I show, in the case in which suits are not settled, that if care is productive (in the sense defined earlier) the optimal award will equal the victim's harm plus the victim's litigation cost. And whether or not care is productive, the optimal award will never exceed this level. This upper bound on the optimal award remains even when the possibility of settlement is taken into account. In the case in which care is not productive, the optimal award is unambiguously less than the level necessary to internalize the victim's litigation cost and expected harms of nonsuing victims.

Polinsky and Rubinfeld (1988a) demonstrates that settlement has conflicting implications for social welfare, because it reduces total litigation costs while also reducing incentives for injurer care. The analysis in this article shows that under a rule that shifts the plaintiff's litigation cost to the defendant, there is no such welfare tradeoff; settlement unambiguously 
enhances social welfare. The reason is that the fee-shifting rule results in either optimal care or excessive care. In the former case, increasing the frequency of settlement reduces only the total litigation cost; in the latter case, increasing the frequency of settlement enhances welfare by reducing both care and the total litigation cost.

Because of the importance of the productivity of care in this analysis, one may wonder whether these results have any practical implications. It happens that the productivity condition identified here is the same as that governing the incentive to waive the right to litigate. Under Coasean conditions, a potential plaintiff will enter into a waiver agreement with a potential defendant whenever the deterrence benefit from a lawsuit is less than the joint cost of litigation (Hylton, 2000). The potential defendants who do not enter into waiver agreements are, then, those for whom care is sufficiently productive that the deterrence benefit exceeds the cost of litigation. Thus, under Coasean conditions, the productivity condition central to several of the results below will be satisfied. I explore the implications of this argument in Section 4.

\section{The Model}

The model, a variant of Polinsky and Rubinfeld (1988a), assumes one risk-neutral injurer and a continuum of risk-neutral victim types; for each victim type, the injurer's care level affects both the probability of harm and the magnitude of harm. I will use the following variables:

$$
\begin{aligned}
& x=\text { injurer's level of care, } \\
& z=\text { index of victim types }(0 \leq z \leq 1), \\
& p(x, z)=\text { probability of harm to victim type } z\left(p_{1}<0, p_{2}>0,\right. \\
& \left.\quad p_{11}>0\right) \text {, } \\
& h(x, z)=\text { harm to victim of type } z\left(h_{1}<0, h_{2}>0, h_{11}>0\right), \\
& f(z)=\text { probability density of } z \text {, where } f(0)=0, \\
& \alpha=\text { victim's cost of litigation, and } \\
& \beta=\text { injurer's cost of litigation. }
\end{aligned}
$$

I assume liability is strict, and (for the moment) that settlement is not an option. Litigation costs are allocated according to the American rule, which requires each party to pay for its own litigation expenses.

A victim will sue if and only if his harm exceeds his litigation cost,

$$
h(x, z)>\alpha \text {. }
$$

Following Polinsky and Rubinfeld (1988a), I will define a threshold level of $z, z(x)$, below which victims will not sue and above which victims will 
sue (given the level of $x$ ),

$$
h(x, z(x))=\alpha .
$$

The injurer's objective is to minimize his costs. Letting TPC stand for "total private costs," the injurer chooses $x$ to minimize

$$
\mathrm{TPC}=x+\int_{z(x)}^{1} p(x, z)[h(x, z)+\beta] f(z) d z
$$

The injurer will choose $x$ so that the "private first-order condition" (PFOC) is equal to zero:

$$
\begin{aligned}
\text { PFOC }= & 1+\int_{z(x)}^{1}\left[p_{1}(x, z) h(x, z)+p(x, z) h_{1}(x, z)\right] f(z) d z \\
& +\int_{z(x)}^{1} p_{1}(x, z) \beta f(z) d z \\
& -p(x, z(x))[h(x, z(x))+\beta] f(z(x)) z^{\prime}(x)=0 .
\end{aligned}
$$

Let $x^{*}$ represent the privately optimal level of care, the level of $x$ that solves (4). The first term on the right hand side of (4) reflects the increase in the injurer's costs from simply taking more care, because care is costly. The second term is negative and reflects the reduction in liability as the injurer's care increases. The third term is negative and reflects the reduction in the injurer's expected litigation cost when he takes more care. The fourth term, which I will call the litigation threshold effect, is also negative and shows that the injurer's liability falls as he takes more care because the threshold level of $z(x)$-the level at which suit becomes profitable to the victim-increases with care. The threshold $z(x)$ increases with injurer care because the victim's harm from injury decreases, which in turn means that more victims fall below the threshold $z(x)$. Thus, the threshold effect reflects the injurer's incentive to take care in order to preclude an additional lawsuit.

Total social cost (TSC) is given by

$$
\mathrm{TSC}=x+\int_{0}^{1} p(x, z) h(x, z) f(z) d z+\int_{z(x)}^{1} p(x, z)(\beta+\alpha) f(z) d z
$$

where the first term represents the cost of care; the second, the cost of injuries; and the third, the expected total cost of litigation. A social planner would choose $x$ to minimize total social cost, setting the following "social 
first-order condition" equal to zero:

$$
\begin{aligned}
\text { SFOC }= & 1+\int_{0}^{1}\left[p_{1}(x, z) h(x, z)+p(x, z) h_{1}(x, z)\right] f(z) \\
& +\int_{z(x)}^{1} p_{1}(x, z)(\beta+\alpha) f(z) d z \\
& -p(x, z(x))(\beta+\alpha) f(z(x)) z^{\prime}(x)=0
\end{aligned}
$$

The first proposition below revisits and extends a basic result, largely to aid interpretation of results that follow.

Proposition 1. Injurers choose a level of care, under strict liability, that is below the socially optimal level.

Proof: Since $h(x, z(x))=\alpha$,

$$
\begin{aligned}
\mathrm{SFOC}= & \mathrm{PFOC}+\int_{z(x)}^{1} p_{1}(x, z) \alpha f(z) d z \\
& +\int_{0}^{z(x)}\left[p_{1}(x, z) h(x, z)+p(x, z) h_{1}(x, z)\right] f(z) d z,
\end{aligned}
$$

where the second term on the right hand side of (7) represents the reduction in the victim's expected litigation costs that results when the injurer takes more care. The third term reflects the reduction in harms to victims who do not sue (because $z$ falls below the threshold level) when the injurer takes more care. Since both terms are negative, the proposition follows.

Injurers exercise socially inadequate care for two reasons: they do not take into account the litigation costs of victims who sue, and they do not consider the losses of victims who do not sue because their litigation expenses exceed their losses (Hylton, 1990). This litigation-cost externality plays a key role below in determining the welfare effects of costly litigation.

The litigation threshold effect does not appear in (7) except through PFOC. Thus, to the extent an increase in care is desirable because it induces the marginal plaintiff not to bring suit, there is no divergence between private and social incentives. Although the injurer does not take $\alpha$ into account explicitly, he is led by the threshold effect to take $h(x, z(x))$ into account, and since $h(x, z(x))=\alpha$ his incentives are socially optimal. This confirms the key result of Menell (1983), that the injurer's incentive to preclude a lawsuit is socially optimal, and demonstrates the connection between Menell's result and the underdeterrence conclusion in Hylton (1990). 


\subsection{Welfare Effects of Cost Changes}

In this section I examine the welfare implications of changes in litigation costs. The results are ambiguous generally, though special cases emerge in which the effects are unambiguous.

Proposition 2. (1) If the victim's harm is independent of the injurer's care level, then the injurer's optimal care level falls as the victim's litigation cost increases; (2) if the victim's harm is dependent on the injurer's care level, then the effect of an increase in the victim's litigation cost on the injurer's optimal care level is ambiguous.

The intuition is as follows. Increasing the victim's cost of litigation has two effects: (1) it makes suit unprofitable for more victims, thus shielding injurers from some lawsuits, and (2) it alters the value to the injurer of precluding an additional lawsuit by taking more care-in essence, the threshold effect. When the severity of the victim's harm is independent of the injurer's care $\left(h_{1}=0\right)$ the threshold effect drops out of this analysis. The reason is that when greater injurer care cannot reduce the victim's harm level, the injurer loses the ability to preclude the marginal plaintiff from suing. Given this, the sole effect of increasing the victim's litigation cost is to shield the injurer from additional lawsuits, and this is why the level of care falls.

When the victim's harm is a function of the injurer's care level, the litigation threshold is potentially significant and complicates the analysis because the impact of increasing the victim's litigation cost on the injurer's incentive to preclude a lawsuit is uncertain. In particular, when the victim's litigation cost increases, the expected value to the injurer of precluding a lawsuit changes, but the direction of change is unclear a priori. To be sure, given that the marginal plaintiff's harm is equal to his cost of litigation, the value of preclusion increases if the victim's litigation cost increases and everything else remains fixed. But everything else may not remain fixed. For example, if the percentage of victims at the threshold level falls sufficiently, the value of preclusion may fall after an increase in the victim's litigation cost.

Proposition 3. If the injurer's optimal level of care declines with the victim's litigation cost $\left(\partial x^{*} / \partial \alpha<0\right)$, then social welfare is decreasing in the victim's litigation cost. If the injurer's optimal care level increases with the victim's litigation cost $\left(\partial x^{*} / \partial \alpha>0\right)$, then the welfare effect of an increase in the victim's litigation cost is ambiguous.

Corollary. If the victim's harm is independent of the injurer's care level, then social welfare falls as the victim's litigation cost rises. 
The explanation for Proposition 3 and its corollary is straightforward. An increase in the victim's litigation cost reduces welfare directly by raising total litigation costs. If the change also leads to a reduction in the injurer's care, then the total impact of an increase in the victim's litigation cost on welfare is unambiguously negative.

Both Propositions 2 and 3 suggest unambiguous results in the case in which harm is independent of the injurer's care. Is there a real-world example for this case? The most plausible is the case in which a failure to take care increases the likelihood of an accident but not the severity of harm. For example, consider a failure to check the amount of fuel before embarking in a plane. This failure to take care increases the likelihood of a plane crash, but not the severity of harm given a crash. More generally, cases of durable precaution as emphasized by Grady (1994) probably fall in the category of cases to which Proposition 3 applies.

Proposition 4. The injurer's optimal level of care increases as his cost of litigation increases.

An increase in the injurer's litigation cost increases the injurer's precaution for two reasons: it increases the cost of failing to take care; and the benefit to the injurer of precluding an additional lawsuit (by raising $z(x))$ increases, also inducing more care.

Proposition 5. If care is productive, in the sense that the marginal deterrence benefit from increasing $\beta$ exceeds the marginal litigation cost, then increasing the injurer's litigation cost leads to an increase in social welfare.

Although both the deterrence benefit and the total litigation cost are increasing in $\beta$, the deterrence benefit is concave and the litigation cost is linear. It follows that if the productivity condition in Proposition 5 holds at sufficiently low levels of $\beta$, there will be a level of $\beta$, call it $\beta^{*}$, at which the marginal deterrence benefit and marginal litigation cost are equalized, thus minimizing social cost. Under these conditions welfare is increasing in $\beta$ for $\beta<\beta^{*}$, and decreasing for $\beta>\beta^{*}$.

Although the welfare effects of increasing litigation costs are ambiguous as a general matter, there is a special case in which clear welfare statements emerge. When the severity of the victim's harm is independent

7. If $\varepsilon_{x}^{p}$ represents the elasticity of $p(x, z)$ with respect to a charge in $x$, and $\varepsilon_{\beta}^{x}$ represents the elasticity of $x$ with respect to a change in $\beta$, then a sufficient condition for welfare to be increasing in the injurer's litigation cost is $\varepsilon_{x}^{p} \varepsilon_{\beta}^{x} \geq \beta / \alpha$ evaluated at $x^{*}$. 
of the injurer's care level, and the deterrence benefit from increasing the injurer's litigation cost exceeds the contribution to total litigation costs, welfare is decreasing in the victim's litigation cost and increasing in the injurer's litigation cost.

\subsection{Optimal Level of Liability}

In this Subsection I examine the optimal adjustment to compensatory damages. If we add some positive amount to the compensatory award, victims will sue more frequently and deterrence will be enhanced. However, once this adjustment is equal to the victim's cost of litigation, suing is essentially free, so further upward adjustments should not encourage additional lawsuits. This suggests that the optimal adjustment will not exceed the victim's cost of litigation, which is confirmed in the following proposition.

Proposition 6. Let $\theta$ be added to compensatory damages, so that the victim receives a judgment equal to $h(x, z)+\theta$.

1. The optimal adjustment $\theta^{*}$ will never exceed $\alpha$.

2. If for all $\theta \leq \alpha$ care is productive (in the sense that the marginal deterrence benefit of increasing $\theta$ is greater than or equal to the marginal litigation cost), then the optimal adjustment $\theta^{*}$ is equal to $\alpha$. Otherwise, the optimal adjustment $\theta^{*}$ is less than $\alpha$ and may be negative.

This is a similar though more detailed result than in Polinsky and Rubinfeld (1988a), which shows that the optimal adjustment to compensatory damages may be positive or negative, depending on the productivity of care. Although this is true, Proposition 6 shows that the adjustment will never exceed the victim's litigation cost, and that in cases in which care is productive (in the sense defined) the optimal adjustment will equal the victim's litigation cost. Productive care cases include those in which the victim's damages are large relative to litigation costs and the injurer's care is highly responsive to changes in the level of the damage award.

One way to understand Proposition 6 is to compare deterrence benefits with litigation costs. The social planner's task is to adjust compensatory damages to a level that maximizes the difference between the deterrence benefit and total litigation cost. The social planner adjusts compensatory damages with a view toward influencing the care choice of the injurer.

If care is productive this is a relatively simple task; for then the private harm-reduction benefits of care can be aligned with the social harm-reduction benefits of care (and deterrence benefits can be maximized) by internalizing external harms to the injurer. External costs are 
internalized to the injurer when the victim's litigation cost is included in damages. Although this maximizes the total litigation cost (because $z\left(x^{*}\right)=0$ ), it is the optimal result when deterrence benefits rise faster than litigation costs at liability levels below the optimal.

If care is unproductive, the social planner will choose an adjustment smaller than the victim's litigation cost, perhaps negative. By choosing a damage award that fails to fully compensate victims, the social planner effectively bars some victims from bringing suit. Barring victims whose harms are relatively small is the same as restricting the right to sue to those whose losses are large. Given larger harms among suing victims, the difference between the deterrence benefit and litigation cost increases. The social planner will reduce the level of the award, thereby barring additional victims from bringing suit, until the difference between the deterrence benefit from suit and litigation cost reaches a maximum. Indeed, if care is extremely unproductive, the social planner will bar all victims from bringing suit, as suggested in Shavell (1982a).

Another way of explaining the optimal damages result in the case in which care is productive relies on Menell's finding that the injurer's incentive to preclude an additional lawsuit is socially optimal. This implies that when care is productive the only role for the social planner is to adjust the level of compensatory damages in order to internalize external harms caused by the injurer. The relevant externalities are two: the litigation costs borne by victims who sue and the harms suffered by victims for whom suit would be unprofitable. These harms are internalized when $\theta=\alpha$.

Consider a special case in which the probability of harm is independent of the victim type, given by $p(x)$, and the harm is simply $z$. The solution to the optimal adjustment problem can be expressed as

$$
\theta^{*}=\alpha+E(z \mid z<\hat{z})\left(\frac{F(\hat{z})}{1-F(\hat{z})}\right)+\frac{(\alpha+\beta) p(x) f(\hat{z})}{p^{\prime}(x)\left(\partial x^{*} / \partial \theta\right)\left(h_{2}\right)(1-F(\hat{z}))}
$$

where $\hat{z}=\alpha-\theta$. This includes the solution $\theta^{*}=\alpha$ as a special case. This equation establishes a link between the litigation context and optimal punishment theory in the case of bilateral precaution (Hylton, 1996a). The first two terms impose a "tax" equal to the sum of the litigation cost of the victim who sues and the expected harm of victims who do not sue. This tax, consistent with optimal punishment theory, places greater weight on the harms of nonsuing victims as the probability of liability falls. The third term (which is negative) allocates part of the social cost of litigation to the victim, in order to induce victims to sue less often. Thus, the optimal adjustment can be expressed as a type of modified optimal penalty, where the solution is pushed below the level of the Becker (1968) model in order to induce care on the part of victims. This special case also reveals that 
when care is unproductive, the optimal adjustment will be less than the optimally deterring tax, which is the sum of the victim's litigation cost and the expected harms of nonsuing victims. ${ }^{8}$

If the model were expanded to allow for two instruments for controlling social welfare--one to control the injurer's care, the other to control the incentive to sue-then it would be possible to ensure optimal care and optimal incentives to sue. This would clearly be desirable in the case in which care is unproductive. For example, one way to control injurer and victim incentives separately would be to tax injurers in order to internalize costs and to make victims pay a fee in order to file a lawsuit. The optimal tax would correct the injurer's incentives by internalizing the harms of victims who do not sue and the litigation costs of those who sue (Hylton, 1990). The filing fee could be set so that the frequency of lawsuits maximizes the difference between the deterrence benefit and total litigation cost. Two-instrument schemes are discussed in Shavell (1996) and Polinsky and Che (1991).

\section{Settlement}

To this point, I have assumed settlement was not an option available to the parties. Now I extend the results to take settlement into account. In addition to modifying the previous results, the results in this part have implications for the social desirability of settlement. ${ }^{9}$

I assume parties incur no legal expenses if they settle. Let $\eta=$ probability of settlement, given suit, and $\sigma=$ injurer's share of settlement surplus. The amount the victim receives, in expectation, is given by $h(z, x)-$ $\alpha+\eta(1-\sigma)(\beta+\alpha)$, where $\beta+\alpha$ is the settlement surplus-the amount saved by settling. The victim's expected payment is equal to his minimum demand, $h(x, z)-\alpha$, plus his expected share of the surplus. The amount the injurer pays, in expectation, is given by $h(z, x)+\beta-\eta \sigma(\beta+\alpha)$, which reflects the injurer's maximum offer, $h(x, z)+\beta$, less his expected portion of the surplus.

Proposition 7. If the injurer receives the total settlement surplus $(\sigma=$ $1)$, then the level of care under strict liability will be less than the socially optimal level. If the injurer shares the settlement surplus with the victim $(\sigma<1)$, then it is unclear whether the injurer's optimal care level is less than the socially optimal level.

8. On the optimal tax, see Hylton (1990, p. 165).

9. See Polinsky and Rubinfeld (1988a), Shavell (1996), and Spier (1997). Unlike Shavell (1996) and Spier (1997), this article does not examine the divergence between private and social incentives to settle. 
Proof: The injurer minimizes

$$
\mathrm{TPC}=x+\int_{z(x)}^{1} p(x, z)[h(x, z)+\beta-\eta \sigma(\beta+\alpha)] f(z) d z .
$$

The social welfare function is given by

$$
\begin{aligned}
\mathrm{TSC}= & x+\int_{0}^{1} p(x, z) h(x, z) f(z) d z \\
& +\int_{z(x)}^{1} p(x, z)(1-\eta)(\beta+\alpha) f(z) d z
\end{aligned}
$$

Taking derivatives and rearranging terms, we get

$$
\begin{aligned}
\mathrm{SFOC}= & \mathrm{PFOC}+\int_{0}^{z(x)}\left(p_{1} h+p h_{1}\right) f(z) d z \\
& +\int_{z(x)}^{1} p_{1}(x, z)[\alpha-\eta(1-\sigma)(\beta+\alpha)] f(z) d z \\
& +p(x, z(x))[\eta(1-\sigma)(\beta+\alpha)] f(z(x)) z^{\prime}(x) .
\end{aligned}
$$

Since the sign of the third term in (11) is unclear, and the sign of the fourth term is positive, the result follows.

There are now three externalities driving a wedge between private and social incentives for precaution. One is due to small-loss victims' deciding not to sue because their litigation costs exceed their expected awards. This externality (as in the no-settlement model) results in injurers taking too little care relative the social optimum.

However, two factors suggest care may go beyond the socially optimal level. One is the expected litigation cost borne by plaintiffs who sue. If the plaintiff receives a sufficiently large share of the settlement surplus, this cost may be zero or negative. When the expected litigation cost is negative, the injurer should take less care, given that his failure to take care bestows a benefit (or is less harmful) to suing victims.

The third factor suggesting the injurer should take less care is the threshold effect. In deciding whether to take care in order to preclude a lawsuit, the injurer considers $h(x, z(x))+\beta-\eta \sigma(\beta+\alpha)$. However, a social planner would be concerned only with the additional social cost generated by the marginal lawsuit, $(1-\eta)(\beta+\alpha)$. In the case of the marginal lawsuit, where $h(x, z(x))=\alpha$, the difference between the injurer's private costs and social costs is $\eta(1-\sigma)(\beta+\alpha)$, which is the plaintiff's share of the settlement surplus. In other words, the injurer has an incentive to exercise too much care because he adds the plaintiff's share of the settlement surplus to the real social cost of the lawsuit.

It should be clear that if $\sigma=1$ (injurer gets the entire settlement surplus), Proposition 1 continues to hold (i.e. strict liability underdeters). 
Since the victim's net litigation costs are positive in this case, the injurer's failure to consider these costs results in socially inadequate precaution. On the other hand, since the injurer appropriates the settlement surplus, he takes into account all relevant costs when deciding whether to raise his care level in order to preclude a lawsuit. Thus, when the injurer gets the entire surplus, the threshold externality disappears, and the litigation-cost externality has the same negative impact on precaution as in the regime without settlement. ${ }^{10}$

The welfare effects of increasing litigation costs are more complicated when settlement is taken into account. When $\sigma=1$, the previous section's analysis of increasing costs remains intact, so Propositions 2 through 5 remain valid. However, when $\sigma<1$ the analysis yields fewer unambiguous results. In addition to the reasons for ambiguity suggested in Proposition 7, there is the additional problem that the effect of an increase in the plaintiff's (or defendant's) litigation cost may be offset by an increase in the plaintiff's (or defendant's) share of the settlement surplus. This makes it difficult to determine the effects of increasing costs on incentives for precaution. If the plaintiff's share of the settlement surplus is nondecreasing in $\alpha$ (which requires $\partial(\eta \sigma) / \partial \alpha \geq 0$ ), then Proposition 2 remains valid in the model with settlement. ${ }^{11}$ Otherwise, the effects of increasing $\alpha$ are ambiguous. Similarly, if the defendant's share of the settlement surplus is nonincreasing in $\beta$ (which requires $1-\eta \sigma-[\partial(\eta \sigma) / \partial \beta](\beta+\alpha) \geq 0)$, then Proposition 4 remains valid in the model with settlement.

Now consider what remains of Proposition 6 when settlement is incorporated. Again assume damages awarded by the court are $h(x, z)+\theta$.

Proposition 8. If the injurer receives the total settlement surplus $(\sigma=$ 1), then Proposition 6 remains valid. If the injurer shares the settlement

10. I should note here that the ambiguous result regarding the optimality of care differs from the analysis in Shavell (1996). Shavell shows that the level of the tax that should be applied to the injurer in order to induce optimal care when settlement is possible. However, Shavell's model assumes that the injurer's share of the settlement surplus is one (i.e., $\sigma=1$ ); thus his result is entirely consistent with this model, given his assumption $\sigma=1$.

11. Two cases come to mind in which this condition probably holds. One is the case in which $\sigma=0$, which is a feature of asymmetric-information models in which the uninformed plaintiff makes the settlement demand (see Bebchuk, 1984). The other is the standard Landes-Posner-Gould settlement model (see, e.g., Shavell, 1982b, for analysis of this model), in which the probability of a settlement increases as the settlement surplus increases. Thus if $\sigma$ remains fixed and the probability of a settlement increases, Propositions 2 and 3 will remain valid in the settlement model. 
surplus with the victim $(\sigma<1)$, then setting $\theta=\alpha$ results in socially excessive care, and the optimal adjustment $\theta^{*}$ is less than $\alpha$.

The intuition is as follows. When the injurer shares the settlement surplus with the victim and $\theta=\alpha$, the victim will be overcompensated by a lawsuit, because he receives as compensation $h(x, z)+\eta(1-\sigma)(\beta+\alpha)$. Put another way, victims are overcompensated since the ones who litigate are fully compensated (both for harm and litigation expenses) and the ones who settle are overcompensated. Given this, the injurer should take less care than is privately optimal.

Now let us consider the effects of settlement on social welfare. Would welfare increase if settlement were prohibited? Polinsky and Rubinfeld (1998a) show that introducing settlement has ambiguous welfare effects, which implies society may be better off reducing the frequency of settlement. The reason is that settlement reduces the total cost of litigation, which enhances welfare, but on the other hand reduces injurers' incentives for care, which reduces welfare. To see the latter point, note that because the plaintiff must maintain the credibility of his threat to sue, litigation costs bar some victims from bringing suit, and to the same extent as in the regime without settlement. On the other hand, a reduction in the injurer's expected litigation cost (because he anticipates settlement) reduces his care level (Proposition 4).

It happens that the welfare tradeoff result of Polinsky and Rubinfeld depends on the assumption that litigation costs are allocated under the American rule. If the victim's litigation cost is shifted to the injurer, then the case for settlement becomes unambiguously positive.

Proposition 9. If damages are adjusted by adding $\theta=\alpha$, then settlement can only enhance social welfare.

In other words, settlement is unambiguously good when damages are adjusted upward by an amount equal to the victim's litigation cost. ${ }^{12}$ In the

12. Although, as noted earlier, this article does not focus on the divergence between private and social incentive; it is a straightforward implication of Proposition 9 that if damages are adjusted upward by $\alpha$, and the probability of settlement is less than one, then the private incentive to settle is inadequate. This is because society always gains from settlement. This result seems to differ from that of Spier (1997), which shows that the private incentive to settle may be excessive. However, Spier (1997) examines a negligence regime, whereas this article examines strict liability. In a negligence regime, with costly litigation and accurate courts, social welfare can be improved by enabling victims to commit to bring suit-this is demonstrated in Spier and suggested by Ordover (1978) (and Hylton, 1990), though the Ordover and Hylton articles do not examine the settlement process. 
case in which the injurer pockets the entire settlement surplus, this follows from the fact that the injurer's care is socially optimal when $\theta=\alpha \alpha$. Given socially optimal care, increasing settlement necessarily reduces social cost. In the case where the injurer shares the settlement surplus with the victim, the injurer takes too much care when $\theta=\alpha$, so increasing the frequency of settlement enhances welfare by reducing the injurer's incentive to take care.

\section{Implications}

With such a simple model one must take care in deriving policy implications. This analysis has implications largely for three issues: optimal damages (including punitive damages), the allocation of litigation costs, and contingency fees or subsidization of litigation.

The key results in this article depend on two conditions. One is whether injurer care is productive when liability is set below the sum of the victim's loss and litigation cost. The other is whether the injurer appropriates the entire settlement surplus. There are good reasons to believe that the first condition will hold when transaction costs are low, and the second will hold generally.

In general, care will be productive when the likelihood of harm falls substantially with injurer care, injurer care is highly responsive to changes in liability, and victim losses are large relative to litigation costs. However, care is also likely to be productive in settings in which transaction costs between the potential victim and injurer are low. When transaction costs are low, the parties can bargain over waiver or arbitration agreements ex ante. If care is not productive, then injurers and victims will have incentives to enter into predispute waiver agreements (Hylton, 2000). Since the deterrence benefit falls short of the total litigation cost in this case, the parties can enhance their joint wealth by entering an agreement in which the victim waives his right to sue the injurer. Alternatively, the parties will have incentives to set up arbitration regimes in which care is productive (e.g., because litigation costs are smaller). Thus, given low transaction costs, care should be productive among those potential victim-injurer pairs that have not entered into waiver or arbitration agreements.

Does it make sense to assume that the injurer generally appropriates the entire settlement surplus? Suppose the injurer offers the victim a settlement that compensates him completely for his harm. If the damage award the court would eventually give the victim is less than the sum of the harm and litigation cost, the victim's threat to sue loses its credibility after the settlement offer, since he cannot improve his position by rejecting the 
offer. Given this, injurers probably can appropriate the entire surplus in most cases. Moreover, an expectation that the injurer will get the surplus could be supported by a rule refusing to enforce the overcompensatory portion of a settlement. The common law rule prohibiting enforcement of penalty clauses in liquidated-damages agreements arguably serves this function already, since a liquidated-damages provision is in essence a predispute settlement agreement.

The upshot is that the results of the simple no-settlement model examined in Section 3 are probably valid in settings where transaction costs are low. In other words, in low-transaction-cost settings, injurers can be induced to exercise optimal care under strict liability merely by setting the damage award equal to the sum of the victim's loss and litigation cost. The remaining sections consider implications for the allocation of litigation costs, punitive damages, and contingency fees.

\subsection{Allocation of Litigation Costs}

The foregoing obviously suggests that shifting the victim's litigation cost to the injurer is the optimal litigation cost-allocation rule in settings where transaction costs are low. Of course, the model here is unrealistically simple in several ways: it assumes strict liability and that the victim always wins his lawsuit. In this model, both the British rule and proplaintiff fee shifting (losing defendant pays) are equivalent. Given this, the finding that the optimal damage award includes the victim's litigation cost can be interpreted as supporting either the British or the proplaintiff rule. Moreover, in a model that allows for the possibility of frivolous lawsuits, the British rule would probably dominate the proplaintiff rule.

When care is unproductive and transaction costs are high, a rule shifting the victim's litigation cost to the injurer will result in socially excessive litigation. For example, automobile drivers have incentives to take care largely to prevent harming themselves rather than avoiding liability, so their precaution is unlikely to be productive because it is unlikely to be highly responsive to changes in liability. Moreover, transaction costs between potential automobile injurers and victims are high, so ex ante waiver and arbitration contracts will not be traded among them. This suggests shifting the victim's litigation cost is not the appropriate allocation rule in the automobile accident setting.

\subsection{Punitive Damages}

Examining a model of strict liability for lapses of care, Polinsky and Shavell (1998) argue that damages should be adjusted upward by dividing the compensatory award by the probability of liability. The model here is narrower in the sense that I assume detection is certain and that the 
plaintiff will prevail. The probability of liability is less than one in this model only because litigation costs bar some victims from suing.

The analysis here suggests one can make a strong argument for capping the supercompensatory portion of damages by the victim's litigation cost in cases involving lapses of care. First, this analysis indicates that an upward adjustment over the compensatory level is appropriate in cases involving lapses of care only when injurer care is productive, and that the adjustment should not exceed the victim's cost of litigation. When care is not productive, the optimal adjustment is negative. In general, the direction of the optimal adjustment to compensatory damages depends on whether enhancing injurer care contributes more to social welfare than reducing litigation costs, and the optimal adjustment itself equates the marginal benefit from deterrence to the marginal cost of litigation.

Second, low-detection cases typically involve intentional harms (e.g., vandalism) rather than lapses of care. Since the criminal law already provides supercompensatory penalties (e.g., prison terms) in the case of intentional harms, there is no apparent need to amplify tort damages for intentional conduct. Moreover, the tort law governing lapses of care has adapted to deal with uncertain detection problems through apportionment rules and through joint and several liability. ${ }^{13}$ One could inflate damages to compensate for the likelihood of losing a lawsuit, but that could generate new costs by eliminating the differential rewards for bringing good and bad legal claims.

In sum, of the reasons one might advance for correcting for the uncertainty of liability, the litigation cost bar-in essence, that high litigation costs effectively prevent some plaintiffs from filing suit-appears to be the only important one that the law has not already compensated for in some sense. This bar can be removed by increasing the damage award up to but not above the plaintiff's cost of litigation.

\subsection{Contingency Fees and Subsidizing Litigation Generally}

Whether subsidizing the bringing of lawsuits is desirable depends, in this model, on the "litigation threshold effect," which captures the injurer's incentive to take care in order to preclude an additional lawsuit. Confirming and extending Menell (1983), this article shows that the injurer's incentive to preclude an additional lawsuit is socially optimal, provided that lawsuits do not settle or the injurer takes the entire settlement surplus.

13. See Kingston v. Chicago \& N.W. Ry. (joint and several liability in the case of fire caused by two independent agents, one of whom is undetected); Summers v. Tice (joint and several liability in the case of two independent agents who act concurrently-only one causes the harm but it is impossible to identify the responsible agent); Sindell v. Abbott Laboratories (market share liability). 
Although the threshold effect simplifies the analysis of care incentives, it complicates analysis of the welfare effects of increasing litigation costs. Consider the effects of increasing the victim's litigation cost. When the threshold effect is zero, as is the case when the severity of injury is unrelated to the injurer's care level, increasing the victim's litigation cost has a predictable result: it reduces welfare by shielding the injurer from lawsuits that would deter careless conduct, which causes the injurer's care to diverge even further from the socially optimal level. However, when the threshold effect is positive, the welfare effect of increasing the victim's litigation cost is ambiguous, because an increase in the victim's litigation cost may enhance the injurer's incentive to take care in order to preclude a lawsuit.

To see the implications of threshold effects in policy analysis, consider the welfare implications of contingency fees. Since they shift risk to the less risk-averse attorney, they have the effect of reducing the victim's litigation cost. If threshold effects are negligible, this analysis implies that contingency fee arrangements enhance social welfare. ${ }^{14}$ On the other hand, if threshold effects are substantial, then the welfare implications of contingency fees are ambiguous.

\section{Conclusion}

This article has reexamined and extended results on the welfare effects of costly litigation under strict liability. My aim has been to pull together disparate analyses under a single framework, reconcile seemingly contradictory results, and extend the analysis. The key result implies that if damages are high relative to litigation costs, and injurer care is highly responsive to changes in the level of liability, lawsuits should be encouraged by making the victim's litigation cost an element of damages. Moreover, under such a cost-shifting scheme, increasing the frequency of settlement could only enhance social welfare.

Of course, it should be kept in mind that I have examined a simple model-one in which the parties are risk neutral, a rule of strict liability applies, and injurers are sued for lapses of care rather than intentional wrongs. I have not allowed for the possibility of bad faith litigation. Relaxing these assumptions may yield different implications for optimal damage

14. Assuming, of course, contingency fee arrangements do not increase the frequency of frivolous claims-which are not considered in this model. Since threshold effects are zero when the victim's harm is independent of the injurer's care level, this suggests a large category of settings in which contingency fees enhance social welfare. I have suggested earlier in this article that cases involving "durable precaution," as emphasized by Grady (1994), probably fall in this category. 
awards. For example, allowing for bad faith lawsuits or for the possibility of legal error may yield the implication that the British rule is superior to one that permits only the successful plaintiff to collect his litigation cost from the defendant. Future research on the welfare effects of litigation should incorporate such features as bad faith litigation, legal error, negligence standards, and intentional wrongs.

\section{Appendix}

Proof of Proposition 2: Let $x^{*}$ represent the injurer's optimal care level, and let $\Delta>0$ represent the second-order condition associated with equation (4). Then

$$
\frac{\partial x^{*}}{\partial \alpha}=\frac{-\left[\frac{\partial \mathrm{PFOC}}{\partial \alpha}\right]}{\Delta}
$$

where

$$
\begin{aligned}
\frac{\partial \mathrm{PFOC}}{\partial \alpha}= & -p_{1}(x, z(x))(\alpha+\beta) f(z(x)) \frac{\partial z}{\partial \alpha} \\
& -p(x, z(x)) f(z)\left[h_{1} \frac{\partial z}{\partial \alpha}+\frac{\partial z}{\partial x}\right] \\
& -p_{2}(x, z(x))(\alpha+\beta) f(z(x)) \frac{\partial z}{\partial \alpha} \frac{\partial z}{\partial x} \\
& -p(x, z(x))(\alpha+\beta) f^{\prime}(z(x)) \frac{\partial z}{\partial \alpha} \frac{\partial z}{\partial x} \\
& -p(x, z(x))(\alpha+\beta) f(z(x)) \frac{\partial^{2} z}{\partial z \partial \alpha} .
\end{aligned}
$$

Using equation (2), we know that as $\alpha$ varies equation (2) traces a relationship of the form $h(x, z(x, \alpha))=\alpha$. It follows from this that $\partial z / \partial \alpha=1 / h_{2}>0$ and $\partial z / \partial x=-h_{1} / h_{2}>0$; so

$$
\begin{aligned}
\frac{\partial \mathrm{PFOC}}{\partial \alpha}= & -p_{1}(x, z(x))(\alpha+\beta) f(z(x))\left(1 / h_{2}\right) \\
& -p_{2}(x, z(x))(\alpha+\beta) f(z(x))\left(-h_{1} / h_{2}^{2}\right) \\
& -p(x, z(x))(\alpha+\beta) f^{\prime}(z(x))\left(-h_{1} / h_{2}^{2}\right) \\
& -p(x, z(x))(\alpha+\beta) f(z(x))\left(-h_{21} / h_{2}^{2}\right) .
\end{aligned}
$$

If $h_{1}=0$, then

$$
\frac{\partial \mathrm{PFOC}}{\partial \alpha}=-p_{1}(\alpha+\beta) f \frac{\partial z}{\partial \alpha}>0 .
$$

and the result follows. 
Proof of Proposition 3: Differentiating the social-cost function evaluated at $x^{*}$, and taking advantage of equation (7), we have

$$
\begin{aligned}
\frac{d \mathrm{TSC}}{d \alpha}= & {\left[\int_{z(x)}^{1} p_{1}(x, z) \alpha f(z) d z\right.} \\
& \left.+\int_{0}^{z(x)}\left[p_{1}(x, z) h(x, z)+p(x, z) h_{1}(x, z)\right] f(z) d z\right]\left.\right|_{x^{*}} \frac{\partial x^{*}}{\partial \alpha} \\
& +\left.\int_{z(x)}^{1} p(x, z) f(z) d z\right|_{x^{*}} .
\end{aligned}
$$

The first component in the bracketed term represents the litigation costs borne by victims who sue. This is negative because an increase in the injurer's care level reduces these costs. The second component in the bracketed term represents the losses borne by victims who do not sue, and this is also negative because these costs fall as the injurer's care increases. If $\partial x^{*} / \partial \alpha<0$ the entire bracketed term of (A5) is positive, and it is negative if $\partial x^{*} / \partial \alpha>0$. The third and final term is positive because it reflects the increase in the deadweight litigation costs that result when $\alpha$ increases. The result follows.

Proof of Proposition 4: Letting $\Delta>0$ represent the second-order condition associated with equation (4),

$$
\frac{\partial x^{*}}{\partial \beta}=\frac{-\left[\frac{\partial \mathrm{PFOC}}{\partial \beta}\right]}{\Delta},
$$

where

$$
\frac{\partial \mathrm{PFOC}}{\partial \beta}=\int_{z(x)}^{1} p_{1}(x, z) f(z) d z-p(x, z(x)) f(z) z^{\prime}(x),
$$

and since this is negative the result follows.

Proof of Proposition 5: Differentiating the social welfare function and evaluating it at $x^{*}$,

$$
\begin{aligned}
\frac{d \mathrm{TSC}}{d \beta}=[ & \int_{z(x)}^{1} p_{1}(x, z) \alpha f(z) d z \\
& \left.+\int_{0}^{z(x)}\left[p_{1}(x, z) h(x, z)+p(x, z) h_{1}(x, z)\right] f(z) d z\right]\left.\right|_{x^{*}} \frac{\partial x^{*}}{\partial \beta} \\
& +\int_{z\left(x^{*}\right)}^{1} p\left(x^{*}, z\right) f(z) d z
\end{aligned}
$$


The first term in (A8) is negative. The second term, also negative, reflects the benefits that result because the injurer takes more care as $\beta$ increases. The third term reflects the increase in deadweight litigation costs and is positive.

Proof of Proposition 6: The injurer's goal is to minimize

$$
x+\int_{z(x)}^{1} p(x, z)[h(x, z)+\theta+\beta] f(z) d z
$$

thus, the injurer chooses $x^{*}$ so that

$$
\begin{aligned}
1 & +\int_{z(x)}^{1}\left(p_{1} h+p h_{1}\right) f(z) d z+\int_{z(x)}^{1} p_{1}(\theta+\beta) f(z) d z \\
& -p(x, z(x))(h+\theta+\beta) f(z) z^{\prime}(x)=0,
\end{aligned}
$$

where $h(x, z(x))=\alpha-\theta$. This yields $x^{*}=x^{*}(\theta)$ and a threshold index $z\left(x^{*}, \theta\right)$. We know from the proof of Proposition 1 that the first-order condition for the social welfare problem (SFOC) can be written in terms of the private first-order condition (PFOC). Differentiating the social welfare function with respect to $\theta$

$$
\begin{aligned}
\frac{d \mathrm{TSC}}{d \theta}=[ & \int_{z\left(x^{*}, \theta\right)}^{1} p_{1}\left(x^{*}, z\right)(\alpha-\theta) f(z) d z \\
& \left.+\int_{0}^{z\left(x^{*}, \theta\right)}\left(p_{1} h+p h_{1}\right) f(z) d z\right] \frac{\partial x^{*}}{\partial \theta} \\
& +\frac{\partial \mathrm{TSC}}{\partial z\left(x^{*}, \theta\right)} \frac{\partial z\left(x^{*}, \theta\right)}{\partial \theta},
\end{aligned}
$$

where

$$
\frac{\partial \mathrm{TSC}}{\partial z\left(x^{*}, \theta\right)}=-(\beta+\alpha) p\left(x^{*}, z\left(x^{*}, \theta\right)\right) f\left(z\left(x^{*}, \theta\right)\right)
$$

The last term of (A11) is positive and reflects the impact of a change in $\theta$ on the suit threshold $z(x)$. Total cost decreases as the threshold level increases; however, the threshold level decreases as $\theta$ increases. The bracketed term in (A11) measures the marginal deterrence benefit of increasing $\theta$, and the last term measures the marginal litigation cost that result from increasing $\theta$.

When $\theta=\alpha$, the first term in (A11) is obviously zero, the second term equals zero because $z\left(x^{*}, \theta\right)=0$, and the third term is equal to zero because $\partial z\left(x^{*}, \theta\right) / \partial \theta=0$. Thus, $\theta=\alpha$ is one solution to the first-order condition $d \mathrm{TSC} / d \theta=0$. However, unless the marginal deterrence benefit is greater than the marginal litigation cost for all $\theta<\alpha$, we may have 
another point at which $d \mathrm{TSC} / d \theta=0$ for some $\theta_{0}<\alpha$. If the marginal deterrence benefit is smaller for some $\theta_{1}$, where $\theta_{0}<\theta_{1}<\alpha$, then $\theta=\alpha$ may not be the global minimum of the social-cost function.

The final step of the argument is to show that the optimal adjustment will never exceed $\alpha$. For $\theta>\alpha$,

$$
\frac{d \mathrm{TSC}}{d \theta}=\left[\int_{0}^{1} p_{1}(\alpha-\theta) f(z) d z\right] \frac{\partial x^{*}}{\partial \theta}>0
$$

and the result follows.

Proof of Proposition 8:

$$
\frac{d \mathrm{TSC}}{d \theta}=\left.\frac{\partial \mathrm{TSC}}{\partial x}\right|_{x^{*}} \frac{\partial x^{*}}{\partial \theta}+\frac{\partial \mathrm{TSC}}{\partial z(x)} \frac{\partial z(x)}{\partial \theta},
$$

where

$$
\begin{aligned}
\frac{\partial \mathrm{TSC}}{\partial x}= & \int_{0}^{z(x)}\left(p_{1} h+p h_{1}\right) f(z) d z \\
& +\int_{z(x)}^{1} p_{1}[\alpha-\theta-(1-\sigma) \beta(\alpha+\beta)] f(z) d z \\
& +p(x, z(x))[\beta(1-\sigma)(\beta+\alpha)] f(z(x)) z^{\prime}(x)
\end{aligned}
$$

If $\sigma=1$, this problem reduces to the equivalent of that observed in Proposition 6. If $\sigma \leq 1$, setting $\theta \geq \alpha$ yields $z(x)=0, z^{\prime}(x)=0$, and $\partial z\left(x^{*}\right) / \partial \theta=0$; so it follows that for $\theta \geq \alpha$

$$
\frac{d \mathrm{TSC}}{d \theta}=[\alpha-\theta-(1-\sigma) \beta(\alpha+\beta)]\left[\int_{0}^{1} p_{1} f(z) d z\right] \frac{\partial x^{*}}{\partial \theta}>0,
$$

in essence, social cost is increasing in $\theta$ for $\theta \geq \alpha$. It is desirable, therefore, to reduce $\theta$ below $\alpha$ in order to encourage the injurer to take less care.

Proof of Proposition 9: Total social cost when settlement is possible is

$$
\begin{aligned}
\mathrm{TSC}= & x+\int_{0}^{1} p(x, z) h(x, z) f(z) d z \\
& +(1-\beta) \int_{z(x)}^{1} p(x, z)(\beta+\alpha) f(z) d z
\end{aligned}
$$

This clearly falls as $\beta$ increases, everything else being fixed. Consider the effect of settlement-induced changes in precaution:

$$
\frac{d \mathrm{TSC}}{d \beta}=\left.\frac{\partial \mathrm{TSC}}{\partial x}\right|_{x^{*}} \frac{\partial x^{*}}{\partial \beta}+\frac{\partial \mathrm{TSC}}{\partial \beta},
$$


where $\partial \mathrm{TSC} / \partial \beta<0$. It follows from Proposition 8 that $\partial \mathrm{TSC} /\left.\partial x\right|_{x^{*}}=0$ when $\sigma=1$, and $\partial \mathrm{TSC} /\left.\partial x\right|_{x^{*}}>0$ when $\sigma<1$. Also, since the injurer's expected payment falls as $\beta$ increases, $\partial x^{*} / \partial \beta<0$, and the result follows.

\section{References}

Bebchuk, Lucian A. 1984. "Litigation and Settlement under Imperfect Information," 13 RAND Journal of Economics 404-15.

Becker, Gary S. 1968. "Crime and Punishment: An Economic Approach," 76 Journal of Political Economy 169-217.

Fiss, Owen M. 1984. "Against Settlement," 93 Yale Law Journal 1073-90.

Grady, Mark F. 1994. "Res Ipsa Loquitor and Compliance Error," 142 University of Pennsylvania Law Review 887-912.

Hylton, Keith N. 2000. "Agreements to Waive or to Arbitrate Legal Claims: An Economic Analysis," 8 Supreme Court Economic Review 209-63.

— 1990. "The Influence of Litigation Costs on Deterrence Under Strict Liability and Under Negligence," 10 International Review of Law and Economics, 161-71.

- 1996a. "Optimal Law Enforcement and Victim Precaution," 27 RAND Journal of Economics 197-206.

1996b, "Rule 68, the Modified British Rule, and Civil Litigation Reform," 1 Michigan Law \& Policy Review 73-98.

Kaplow, Louis. 1986. "Private versus Social Costs in Bringing Suit," 15 Journal of Legal Studies 371-85.

Kingston v. Chicago \& N.W. Ry., 211 N.W. 913 (Wis 1927).

Menell, Peter S. 1983. "A Note on Private versus Social Incentives to Sue in a Costly Legal System," 12 Journal of Legal Studies 41-52.

Ordover, Janusz A. 1978. "Costly Litigation in the Model of Single Activity Accidents," 7 Journal of Legal Studies 243-61.

Polinsky, A. Mitchell, and Yeon-Koo Che. 1991. "Decoupling Liability: Optimal Incentives for Care and Litigation," 22 RAND Journal of Economics 562-70.

Polinsky, A. Mitchell, and Daniel L. Rubinfeld. 1988a. "The Deterrent Effects of Settlements and Trials," 8 International Review of Law and Economics 109-16.

- 1988b. "The Welfare Implications of Costly Litigation for the Level of Liability," 17 Journal of Legal Studies 151-64.

Polinsky, A. Mitchell, and Steven Shavell. 1998. "Punitive Damages: An Economic Analysis," 111 Harvard Law Review 869-962.

Posner, Richard A. 1973. "Strict Liability: A Comment," 2 Journal of Legal Studies 205-21. 
Rose-Ackerman, Susan, and Mark Geistfeld. 1987. "The Divergence Between Social and Private Incentives to Sue: A Comment on Shavell, Menell, and Kaplow," 16 Journal of Legal Studies 483-91.

Shavell, Steven. 1982a. "The Social versus the Private Incentive to Bring Suit in a Costly Legal System," 11 Journal of Legal Studies 333-39.

. 1982b. "Suit, Settlement, and Trial: A Theoretical Analysis under Alternative Methods for the Allocation of Legal Costs," 11 Journal of Legal Studies 55-81.

. 1996: "The Level of Litigation: Private versus Social Optimality," Harvard Law School Discussion Paper 184, John M. Olin Center for Law, Economics, and Business.

1997. "The Fundamental Divergence between Private and Social Incentive to Use the Legal System," 26 Journal of Legal Studies 575-612.

Sindell v. Abbott Laboratories, 607 p. 2d 924 (Cal. 1980).

Spier, Kathryn. 1997. "A Note on the Divergence between the Private and Social Motive to Settle under a Negligence Rule," 26 Journal of Legal Studies 613-22. Summers v. Tice, 199 p. 2d 1 (Cal. 1948). 